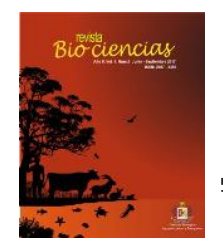

\title{
Harvest Index and Refrigeration in Lisianthus (Eustoma grandiflorum (Raf.) Shin.) 'Magic Blue'
}

\section{Refrigeración e Índice de Cosecha en Lisianthus (Eustoma grandiflorum (Raf.) Shin.) 'Magic Blue'}

\author{
Pérez-Arias, G.A. ${ }^{1}{ }^{2 *}$, Alia-Tejacal, I. ${ }^{1}$, Valdez-Aguilar, L.A. ${ }^{2}$, Colinas-León, M.T. ${ }^{3}$, Sainz-Aispuro, M. ${ }^{1}$. \\ ${ }^{1}$ Universidad Autónoma del Estado de Morelos, Posgrado en Ciencias Agropecuarias, \\ Av. Universidad, Núm. 1001, Col. Chamilpa, C.P. 62209. Cuernavaca, Morelos. México. \\ 2Universidad Autónoma Agraria Antonio Narro, Departamento de Horticultura, \\ Calzada Antonio Narro 1923. C.P. 25315. Saltillo, Coahuila. México. \\ ${ }^{3}$ Universidad Autónoma Chapingo, Departamento de Fitotecnia, Carretera \\ México-Texcoco, Km. 38.5. C.P. 56230. Chapingo, Estado de México. México.
}

\section{A B S T R AC T}

Inflorescences of lisianthus 'Magic Blue' were harvested with one, two or three open basal flowers and maintained at 15 or $25^{\circ} \mathrm{C} ; 85 \%$ of relative humidity $(\mathrm{RH})$ to evaluate changes during vase life in order to determine the best harvest index. Inflorescences maintained under $15{ }^{\circ} \mathrm{C}$ obtained the highest water uptake, the pure purple color and lightness $(h=297.5$, $C^{*}=32.5$ and $L^{*}=34.5$ ), consequently better appearance by 13 days than inflorescences stored at $25^{\circ} \mathrm{C}$, which showed regular appearance by 10 days. However, in inflorescences stored at $25{ }^{\circ} \mathrm{C}$ the highest number of open flowers was quantified. Inflorescences harvested with greater number of open flowers showed greatest total number of open flowers at the end of the experiment, approximately 1 or 2 flowers are opened during vase life, regardless of the number of flowers with which the inflorescence is harvested. Thus, results indicate that storage at $15{ }^{\circ} \mathrm{C}$ increased shelf life of lisianthus 'Magic Blue' by 3 days. No effect was observed in quality parameters by the harvest index.

Article Info/Información del artículo

Received/Recibido: September $3^{\text {rd }} 2016$.

Accepted/Aceptado: November $23^{\text {rd }} 2016$.

\section{RES U M E N}

Se cosecharon inflorescencias de lisianthus 'Magic Blue' con una, dos ó tres flores basales abiertas y se mantuvieron a 15 ó $25^{\circ} \mathrm{C}$; $85 \%$ de HR (humedad relativa) para evaluar algunos cambios durante poscosecha con la finalidad de determinar el mejor índice de cosecha. Las inflorescencias almacenadas a $15{ }^{\circ} \mathrm{C}$ mantuvieron mayor consumo de agua, el color morado con mayor pureza y brillo $\left(h=297.5, C^{*}=32.5\right.$ y $\left.L^{*}=34.5\right)$ en consecuencia mejor apariencia por 13 días que las flores almacenadas a $25^{\circ} \mathrm{C}$, las cuales mostraron regular apariencia por 10 días. Sin embargo, abrieron el mayor número de flores en los tallos almacenados a $25^{\circ} \mathrm{C}$. Las inflorescencias cosechadas con mayor número de flores abiertas mostraron mayor número total de flores abiertas al final del experimento; en promedio abren 1 ó 2 flores más durante poscosecha. Así, los resultados indican que el almacenamiento a $15{ }^{\circ} \mathrm{C}$ incrementó la vida útil de lisianthus 'Magic Blue' por 3 días. El índice de cosecha no afecta los parámetros de calidad.

\section{P A L A B R A S C L V E}

Poscosecha; apertura floral; consumo de agua; color.

*Corresponding Author:

Gloria Alicia Pérez-Arias. Universidad Autónoma del Estado de Morelos, Posgrado en Ciencias Agropecuarias, Av. Universidad, Núm. 1001, Col. Chamilpa, Cuernavaca, Morelos. C.P.62209. Phone: +52(777) 3230 749. E-mail: yoyaly@hotmail.com 


\section{K E Y W O R D S}

Postharvest, open flower, water uptake, color.

\section{Introduction}

Lisianthus (Eustoma grandiflorum (Raf.) Shin) is a herbaceous plant used as cut flower, pot flower and garden plant (Dole and Wilkins, 2005). It is original from southern United States, from Colorado to Nebraska, and northern Mexico (Huxley et al., 1992). The popularity of lisianthus is attributed to the varied and attractive colors of its flowers (Islam et al., 2003). Flowers can be simple or double, between 5.0 and 9.5 $\mathrm{cm}$ of diameter with colors ranging from white, green, yellow, pale to dark pink, violet, purple and sometimes bicolor (Dole and Wilkins, 2005).

Lisianthus has acquired great importance in the world as cut flower (De la Riva et al., 2009); each inflorescence can have up to 10 individual flowers, and the plant, depending if annual or biannual, can generate up to 10 inflorescences during production season (Cho et al., 2001). In Europe, 50 million stems are growth, main producers are: Holland, Spain, Italy, Portugal and France (Namesny, 2005). In 2011, the value of total sales of lisianthus in the United States was 3.16 million dollars, where the state of California was the entity that produced $99 \%$ of total production (USDA, 2012). In Mexico, lisianthus is a recent introduction species which demand in the national market is rising, hence it is considered to be a culture with wide perspectives (Cruz-Crespo et al., 2006).

In Mexico, after the harvest of inflorescences, these are transferred to the packaging area, where basal leaves are eliminated and stems are selected based in their quality, so that they can be placed in bouquets, and finally in water for the transportation or sale (Pérez-Arias et al., 2014). Transportation to sale points at retail is dry, with no refrigeration, and transportation time varies between 2 to $12 \mathrm{~h}$, which can significantly affect its vase life (Ahmad et al., 2012; Pérez-Arias et al., 2014). Reid and Jiang (2012) indicate that postharvest life of cut flowers decreases up to $40 \%$ due to the lack of temperature management during transportation. Temperature influences in breathing velocity, ethylene response, water loss and physical damage in several cut flowers (Cevallos and

\section{Introducción}

El lisianthus (Eustoma grandiflorum (Raf.) Shin) es una planta herbácea utilizada como flor de corte, de maceta y como planta de jardín (Dole y Wilkins, 2005). Es una planta originaria del sur de Estados Unidos, desde Colorado y Nebraska, y del norte de México (Huxley et al., 1992). La popularidad del lisianthus se atribuye a los variados y atractivos colores de sus flores (Islam et al., 2003). Las flores pueden ser simples o dobles, de entre 5.0 y 9.5 $\mathrm{cm}$ de diámetro con colores que van desde blanco, verde, amarillo, rosa pálido a oscuro, lila, púrpura y en ocasiones bicolores (Dole y Wilkins, 2005).

El lisianthus ha adquirido gran importancia en el mundo como flor de corte (De la Riva et al., 2009), cada inflorescencia puede tener hasta 10 flores individuales y la planta dependiendo si es anual o bianual puede generar hasta 10 inflorescencias durante la temporada de producción (Cho et al., 2001). En Europa, se cultivan 50 millones de tallos, siendo los principales países productores: Holanda, España, Italia, Portugal y Francia (Namesny, 2005). En 2011, el valor de las ventas totales de lisianthus en Estados Unidos fue de 3.16 millones de dólares, donde el estado de California fue la entidad que produjo $99 \%$ de la producción total (USDA, 2012). En México, el lisianthus es una especie de reciente introducción cuya demanda en el mercado nacional va en aumento, por lo que se considera un cultivo con amplias perspectivas (Cruz-Crespo et al., 2006).

En México, después de la cosecha de las inflorescencias, éstas son transferidas al área de empaque donde se eliminan las hojas basales y se seleccionan los tallos en base a su calidad, para luego ser colocados en bouquets y finalmente en agua para su posterior transporte o venta (PérezArias et al., 2014). El transporte a lugares de venta al menudeo es en seco, sin refrigeración y el tiempo de transporte varía entre 2 y $12 \mathrm{~h}$, lo cual puede afectar significativamente su vida en florero (Ahmad et al., 2012; Pérez-Arias et al., 2014). Reid y Jiang (2012) indican que la vida poscosecha de las flores de corte disminuye hasta $40 \%$ debido a la falta de manejo de la temperatura durante el transporte. La temperatura influye en la velocidad de respiración, la respuesta al etileno, pérdida de agua y daño físico en varias flores de corte (Cevallos y Reid, 2001). Una vez cortadas las flores, a medida que la temperatura aumenta, también lo hace la respiración y los procesos metabólicos, de manera que la refrigeración puede disminuir dramáticamente la tasa de envejecimiento (Nell y Reid, 2002). En lisianthus, 
Reid, 2001). Once flowers are cut, as temperature rises, so does the breathing and metabolic processes, hence the refrigeration can dramatically increase in the aging rate (Nell and Reid, 2002). In lisianthus, there is few information on the effect of temperature, especially in lisianthus growth in the State of Morelos, in warm weather conditions.

Dole and Wilkins (2005) indicate that the inflorescences of lisianthus can be harvested with one or more open flowers, and with the flower buds with the incipient development of color of the petals. Nell and Reid (2000) suggest buying the lisianthus when a flower is open and with several big buds. Other reports suggest harvesting lisianthus with one or two open flowers (de la Riva et al., 2009; Harbaugh et al., 2000; Hassanpour and Karimi, 2010; Kazemi et al., 2011), but overall, there is no indication on the postharvest life of inflorescences when the harvest index is determined by the number of open flowers.

In consequence, this work aimed to study the effect of the harvest index (floral stem harvested with one, two or three open flowers) and the storage temperature (15 and $20{ }^{\circ} \mathrm{C}$ ) in postharvest life of lisianthus 'Magic Blue' cultured in Morelos, Mexico.

\section{Materials and Methods}

Stems of lisianthus 'Magic Blue' cultured under a plastic cover were obtained in Zacatepec, Morelos, which average climate conditions in culture period were $24.5^{\circ} \mathrm{C}$ and $69.1 \%$ of $\mathrm{RH}$. Stems were harvested and immediately placed in distilled water and transported to the laboratory, where they were cut at $45 \mathrm{~cm}$, and basal leaves of the first $20 \mathrm{~cm}$ were eliminated. Stems with no mechanical or parasitological damage were selected.

\section{Experimental organization}

The harvest index $(\mathrm{HI})$ was evaluated at three levels in this experiment: inflorescences of lisianthus with one, two, or three open basal flowers; storage temperature with two levels: 15 or $25{ }^{\circ} \mathrm{C}$. The combination of all factors with their levels originated the formation of 6 groups with six floral stems each. After, all inflorescences groups were taken to controlled temperature chambers of 15 and $25{ }^{\circ} \mathrm{C}$, both with $\mathrm{RH}$ of $85 \pm 1 \%$ and luminous period of $12 \mathrm{~h}$ with radiation of $173 \pm 50 \mu \mathrm{mol} \mathrm{m} \mathrm{m}^{-2} \mathrm{~s}^{-1}$ and a darkness period of $12 \mathrm{~h}$. The inflorescences were evaluated during the period of their shelf life, which was defined existe poca información sobre el efecto de la temperatura, sobre todo en lisianthus cultivados en el estado de Morelos, en condiciones de clima cálido.

Dole y Wilkins (2005) indican que las inflorescencias de lisianthus pueden ser cosechadas con una o más flores abiertas y con las yemas florales con el desarrollo incipiente del color de los pétalos. Nell y Reid (2000) sugieren comprar los lisianthus cuando se tenga una flor abierta y varios botones grandes. Otros reportes sugieren cosechar los lisianthus entre una ó dos flores abiertas (de la Riva et al., 2009; Harbaugh et al., 2000; Hassanpour y Karimi, 2010; Kazemi et al., 2011) pero en general no se indica cual es el efecto en la vida poscosecha de las inflorescencias cuando el índice de cosecha se determina por el número de flores abiertas.

Considerando lo anterior, en el presente trabajo se tuvo como objetivo estudiar el efecto del índice de cosecha (tallo floral cosechado con una, dos ó tres flores abiertas) y la temperatura de almacenamiento $\left(15\right.$ y $\left.20^{\circ} \mathrm{C}\right)$ en la vida poscosecha de lisianthus 'Magic Blue' cultivados en Morelos, México.

\section{Materiales y Métodos}

Se obtuvieron tallos de lisianthus 'Magic Blue' cultivados bajo cubierta plástica en Zacatepec, Morelos cuyas condiciones climáticas promedio en el periodo del cultivo fueron de $24.5^{\circ} \mathrm{C}$ y $69.1 \%$ de HR. Los tallos fueron cosechados e inmediatamente colocados en agua destilada y se trasladaron al laboratorio, donde se recortaron a $45 \mathrm{~cm}$ y se eliminaron las hojas basales de los primeros 20 $\mathrm{cm}$. Se seleccionaron tallos que no tuvieran daños mecánicos o parasitológicos.

\section{Organización experimental}

En el experimento se evaluó el Índice de Cosecha (IC) a tres niveles: inflorescencias de lisianthus con una, dos ó tres flores basales abiertas; y la temperatura de almacén con dos niveles: 15 ó $25{ }^{\circ} \mathrm{C}$. La combinación de todos los factores con sus niveles originó la formación de 6 grupos con seis tallos florales cada uno. Posteriormente todos los grupos de inflorescencias fueron trasladadas a cámaras de temperatura controlada de $15^{\circ} \mathrm{C}$ y $25^{\circ} \mathrm{C}$, ambas con una H.R. de $85 \pm 1 \%$ y periodo luminoso de $12 \mathrm{~h}$ con radiación de $173 \pm 50 \mu \mathrm{mol} \mathrm{m} \mathrm{m}^{-2} \mathrm{~s}^{-1} \mathrm{y}$ un periodo de oscuridad de $12 \mathrm{~h}$. Las inflorescencias se evaluaron durante el periodo de su vida útil, el cual se definió como los 
as the days that each inflorescence reached $50 \%$ of the withered flowers (Chamani et al., 2009).

Flower stems were kept in tubes with distilled water during the evaluation. Measurement of the response variables, made in lab conditions: $50 \mu \mathrm{mol} \mathrm{m} \mathrm{m}^{-2} \mathrm{~s}^{-1}$ of radiation PAR, R.H. of $60 \pm 5 \%$ and temperature de $19 \pm 2{ }^{\circ} \mathrm{C}$. Once measurements were finished, inflorescences were returned to the environment chambers immediately controlled.

\section{Evaluated variables}

Relative fresh weight. At the beginning of the experiment, inflorescences were weighed in a digital scale (OHAUS $\AA$, USA); after, this variable was evaluated every three days during shelf life of the inflorescence. Relative weight is shown as the percentage of change in mass of inflorescences considering initial weight as $100 \%$.

Color components. Two readings from the central part of each flower were taken, depending on the number of flowers of the floral stem to finally take the average. A portable spectrophotometer (X-rite ${ }^{\circledR}$ mod. 3290, USA) was used, which was programmed to provide values of luminosity $\left(L^{*}\right)$, where values of $L^{*}=0$ represent black, and $L^{*}=100$, white; chromaticity $\left(C^{*}\right)$, which indicates pureness of color and is expressed as the distance from the origin in a color circle; and hue (h), which represents true color, $h=0$ indicates reddishpurple, $\mathrm{h}=90$ indicates yellow, $\mathrm{h}=180$ indicates green, $h=270$ indicates blue, etc. (Negueruela, 2012). This variable was measured every third day.

The number of open flowers was evaluated from the first day inflorescences were placed in tubes, and the number of open flowers was counted every three days by floral stem. The accumulated number of open flowers was reported.

Appearance. It was measured in each inflorescence every three days by a hedonic scale where $4=$ excellent, $3=$ good, $2=$ regular and $1=$ bad. To consider which flower had an excellent appearance it had to be turgid, with no signal of wilt and the coloring corresponding to variety.

Water consumption. Each inflorescence was placed in a tube with a known volume of distilled water (250 $\mathrm{mL})$, the consumed volume was evaluated every días en que cada inflorescencia alcanzó $50 \%$ de las flores marchitas (Chamani et al., 2009).

Los tallos florales se mantuvieron en probetas con agua destilada durante la evaluación. La medición de las variables respuesta, las cuales se hicieron en condiciones de laboratorio: $50 \mu \mathrm{mol} \mathrm{m} \mathrm{m}^{-2} \mathrm{~s}^{-1}$ de radiación PAR, H.R. del $60 \pm$ $5 \%$ y temperatura de $19 \pm 2{ }^{\circ} \mathrm{C}$. Una vez terminado con las mediciones, las inflorescencias se regresaban a las cámaras de ambiente controlado inmediatamente.

\section{Variables evaluadas}

Peso fresco relativo. Al inicio del experimento se pesaron las inflorescencias en una balanza digital (OHAUS®, USA), posteriormente esta variable se evaluó cada tres días durante la vida útil de la inflorescencia. El peso relativo se presenta como el porcentaje de cambio en masa de las inflorescencias considerando el peso inicial como el $100 \%$.

Componentes del color. Se tomaron dos lecturas de la parte central de cada flor, en dependencia del número de flores del tallo floral, para finalmente promediarlas. Se utilizó un espectrofotómetro portátil (X-rite® mod. 3290, USA), el cual fue programado para proporcionar valores de luminosidad $\left(L^{*}\right)$, donde valores de $L^{*}=0$ representan el negro y $L={ }^{*} 100$, el blanco; cromaticidad $\left(C^{*}\right)$, que indica la pureza del color y es expresada como la distancia desde el origen en un circulo de color; y matiz (h), que representa el color verdadero, $h=0$ indica un color rojo-morado, $h=90$ indica un color amarillo, $h=180$ indica aun color verde, $h=270$ indica un color azul, etc. (Negueruela, 2012). Ésta variable se midió cada tercer día.

El número de flores abiertas, se evaluó desde el primer día de colocadas las inflorescencias en probetas y cada tres días se contó el número de flores abiertas por tallo floral. Se reportó el número acumulado de flores abiertas.

Apariencia. Se midió cada tres días en cada inflorescencia mediante una escala hedónica donde $4=$ excelente, $3=$ buena, $2=$ regular y $1=$ mala. Para considerar que una flor tenía apariencia excelente debía estar turgente, sin mostrar signos de marchitez y con la coloración correspondiente a la variedad.

Consumo de agua. Cada inflorescencia se colocó en una probeta con un volumen conocido de agua destilada (250 mL), cada tres días se evaluó el volumen consumido por 
three days by each floral stem, total volume was completely renewed with new distilled water when evacua- tion was made.

\section{Data analysis}

A completely randomized experimental design was used, with factorial arrangement. The experimental unit was an inflorescence of lisianthus with six repeti- tions. The obtained data were studied through a variance analysis and mean comparison by a Tukey test $(p<0.05)$ with the SAS® V. 9.1 software (Castillo, 2011). Relative fresh weight, number of open flowers and appearance were transformed by obtaining the squared root from the data before performing the variance analysis.

\section{Results and Discussion}

\section{Relative fresh weight}

Relative fresh weight was affected by the interaction of storage harvest index $(\mathrm{HI})$ and tempera- cada tallo floral, el volumen total se renovó completamente con agua destilada nueva cuando se realizaba la evaluación.

\section{Análisis de datos}

Se utilizó un diseño experimental completamente al azar, con arreglo factorial. La unidad experimental fue una inflorescencia de lisianthus con seis repeticiones. Los datos obtenidos fueron estudiados mediante un análisis de varianza y comparación de medias por el método de Tukey $(p<0.05)$ con el software SAS $\AA$ V. 9.1 (Castillo, 2011). El peso fresco relativo, número de flores abiertas y apariencia fueron tranformados al obtener la raíz cuadrada de los datos antes de realizar el análisis de varianza.

\section{Resultados y Discusión}

\section{Peso fresco relativo}

El peso fresco relativo fue afectado por la interacción del Índice de Cosecha (IC) y la temperatura (T) de almacenamiento (Tabla 1 ). El peso fresco relativo se incrementó en todos los tratamientos al día cuatro de

Table 1.

Response of some physical variables to the storage in different temperatures and harvest index in lisianthus 'Magic Blue'

Tabla 1.

Respuesta de algunas variables físicas al almacenamiento en diferentes temperaturas e índice de cosecha en lisianthus 'Magic Blue'

\begin{tabular}{|c|c|c|c|c|c|c|c|}
\hline Factor & $\begin{array}{c}\text { Relative Fresh } \\
\text { Weight (\%) }\end{array}$ & $L^{*}$ & $C^{*}$ & $\mathrm{~h}$ & $\begin{array}{l}\text { Open Flowers } \\
\text { (No.) }\end{array}$ & Appearance & $\begin{array}{l}\text { Water Con- } \\
\text { sumption } \\
\quad(\mathrm{mL})\end{array}$ \\
\hline \multicolumn{8}{|l|}{ Level } \\
\hline \multicolumn{8}{|l|}{ Temperature $(\mathrm{T})$} \\
\hline $15^{\circ} \mathrm{C}$ & $103.2^{\mathrm{a}}$ & $34.5^{\mathrm{a}}$ & $32.5^{\mathrm{a}}$ & $297.5^{a}$ & $2.9^{b}$ & $3.0^{\mathrm{a}}$ & $33.8^{\mathrm{a}}$ \\
\hline $25^{\circ} \mathrm{C}$ & $103.3^{a}$ & $33.2^{\mathrm{b}}$ & $30.1^{b}$ & $296.4^{b}$ & $3.4^{\mathrm{a}}$ & $2.5^{b}$ & $29.2^{b}$ \\
\hline DMSH & 1.58 & 0.89 & 1.12 & 0.37 & 0.20 & 0.25 & 1.78 \\
\hline \multicolumn{8}{|c|}{ Harvest Index (HI) } \\
\hline 1 open flower & $102.1^{b}$ & $33.9^{a}$ & $30.8^{a}$ & $296.8^{a}$ & $2.3^{c}$ & $2.77^{a}$ & $31.4^{a}$ \\
\hline 2 open flowers & $101.2^{b}$ & $33.5^{\mathrm{a}}$ & $31.2^{\mathrm{a}}$ & $297.2^{a}$ & $3.0^{b}$ & $2.65^{a}$ & $32.2^{a}$ \\
\hline 3 open flowers & $106.5^{a}$ & $34.1^{\mathrm{a}}$ & $31.7^{\mathrm{a}}$ & $296.9^{a}$ & $4.2^{\mathrm{a}}$ & $2.99^{a}$ & $31.0^{\mathrm{a}}$ \\
\hline DMSH & 2.31 & 1.30 & 1.64 & 0.55 & 0.29 & 0.36 & 2.61 \\
\hline C.V. (\%) & 7.7 & 12.9 & 52.4 & 0.6 & 16.23 & 24.2 & 13.0 \\
\hline $\mathrm{T}^{*} \mathrm{IC}$ & * & NS & NS & * & NS & NS & ** \\
\hline
\end{tabular}



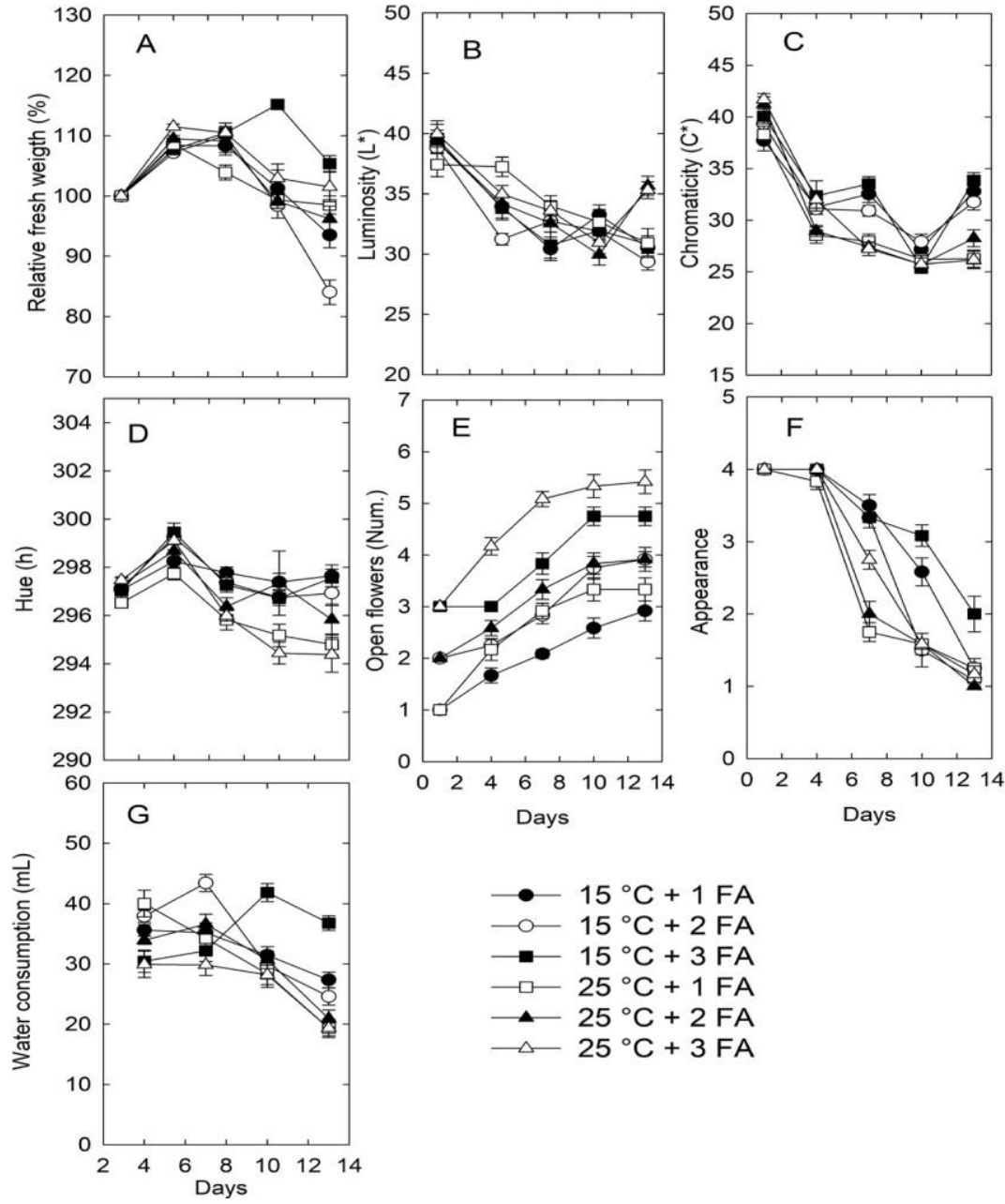

Figure 1. Changes in relative fresh weight (A), luminosity (B), chromaticity (C), hue (D), number of open flowers (E) appearance (F) and water consumption (G) of inflorescences of lisianthus 'Magic Blue' harvested with one, two or three basal open flowers and stored at 15 or $25^{\circ} \mathrm{C}$. Each point represents the average of six observations and standard error bars.

Figura 1. Cambios de peso fresco relativo (A), luminosidad (B), cromaticidad (C), matiz (D), número de flores abiertas $(E)$, apariencia $(F)$ y consumo de agua $(G)$ de inflorescencias de lisianthus 'Magic Blue' cosechados con una, dos o tres flores basales abiertas y almacenados a 15 ó $25^{\circ} \mathrm{C}$. Cada punto representa la media de seis observaciones y las barras el error estándar.

ture $(T)$ (Table 1). Relative fresh weight increased in all treatments on the fourth day of evaluation between $7.7 \%$ and $11.5 \%$, and it was kept between $9.1 \%$ and $12.8 \%$ on day 7 (Figure $1 \mathrm{~A}$ ). After, at day 10 of evaluation, relative weight decreased in al treatments between 0.8 and $3.0 \%$ with respect to initial day, except harvested stems with open flowers and maintained at $15^{\circ} \mathrm{C}$, which showed $15.2 \%$ higher fresh weight with respect to initial day $(p \leq 0.05$; Figure $1 \mathrm{~A}$ ). Finally, on the 13 day of evaluation, floral stems harvested with three open flowers kept $5.3 \%$ major relative fresh weight with respect to evaluación entre $7.7 \%$ y $11.5 \%$, y se mantuvo entre $9.1 \%$ y $12.8 \%$ en el día 7 (Figura $1 \mathrm{~A}$ ). Posteriormente al día 10 de evaluación, el peso relativo disminuyó en todos los tratamientos entre 0.8 y $3.0 \%$ con respecto al día inicial, a excepción de los tallos cosechados con tres flores abiertas y mantenidas a $15 \mathrm{C}$, las cuales mostraron $15.2 \%$ mayor peso fresco con respecto al día inicial ( $p \leq 0.05$; Figura $1 \mathrm{~A}$ ). Finalmente, en el día 13 de evaluación, los tallos florales cosechados con tres flores abiertas mantuvieron $5.3 \%$ mayor peso fresco relativo con respecto al día inicial (Figura $1 \mathrm{~A}$ ). El 
initial day (Figure $1 \mathrm{~A}$ ). Initial increase in the relative fresh weight of lisianthus 'Magic Blue' may be due to the hydration of inflorescences, while the posterior decrea- se of relative weight in most of the treatments is attri- buted to an imbalance between water consumption and transpiration (Finger et al., 2015). Some factors that cause the decrease in the consumption of water are the development of microorganisms that obstruct the xylem, phenols and pectin and embolism (Van-Doorn, 2012). Liao et al., (2001) indicate that lisianthus 'Hei Hou' har- vested with 2 or 3 open flowers and placed in distilled water (25 ${ }^{\circ} \mathrm{C}, 70 \% \mathrm{RH}$ and $15 \mu \mathrm{mol} \mathrm{s}{ }^{-1}$ of luminous intensity) had a decrease in fresh weight after 6 days in these conditions, which agrees with the results obser-ved in this study.

\section{Color components}

Luminosity of petals decreased during postharvest life (Figure 1B). Luminosity was significantly affec- ted by storage temperature $(p \leq 0.05 ;$ Table 1$)$; hence, inflorescences changed initial values of $L^{*}$ between

37.2 and 39.9 to 29.9 and 33.2 after 10 days (Figure $1 \mathrm{~B})$, which indicates that there was a tendency towards black, attributable to a darkening in the petals when flowers perished.

Chromaticity significantly decreased in the inflorescen- ces ( $p \leq 0.05$ ), initial values of $C^{*}$ between 37.7 and 41.6 to 26.1 and 33.8 at the end of the experiment (Figure $1 \mathrm{C}$ ). Stored flowers at $25^{\circ} \mathrm{C}$ were more opaque from the fourth day of evaluation and this tendency was kept until the end of the experiment (Figure $1 \mathrm{C}$ ).

On the other hand, the color of the inflorescences was affected by the interaction $\mathrm{HI} \times \mathrm{T}$ (Table 1). Initial coIor of 'Magic Blue' inflorescences was close to purple ( $h=$ between 296.5 and 297.4), flowers kept at $15^{\circ} \mathrm{C}$ showed few change during the study ( $\mathrm{h}=$ between 296.9 and 297), not so for the inflorescences stored at $25^{\circ} \mathrm{C}$, in which a tendency towards blue color was observed ( $h=$ between 294 and 295.8) (Table 1; Figure 1 D). The latter indicates that temperature accelerated the senescence process of the flower, which is characterized by an oxidation of the anthocyanins present in the petals (Oren-Shamir et al., 1999). Overall, color components were kept in better condition than when flowers were stored at $15^{\circ} \mathrm{C}$. inremento inicial en el peso fresco relativo en lisianthus 'Magic Blue' puede deberse a que las inflorescencias se hidrataron nuevamente, mientras que la posterior disminución de peso relativo en la mayoría de los tratamientos se atribuye a un desbalance entre el consumo de agua y la transpiración (Finger et al., 2015). Algunos factores que ocasionan la disminución del consumo de agua son el desarrollo de microorganismos que obstruyen el xilema, la deposición de fenoles y pectinas y el embolismo (Van-Doorn, 2012). Liao et al., (2001) indican que lisianthus 'Hei Hou' cosechadas con 2 ó 3 flores abiertas y colocadas en agua destilada $\left(25{ }^{\circ} \mathrm{C}\right.$, $70 \% \mathrm{HR}$ y $15 \mu \mathrm{mol} \mathrm{s}{ }^{-1}$ de intensidad luminosa) tuvieron una disminución en el peso fresco después de 6 días en estas condiciones, lo que concuerda con los resultados observados en el presente estudio.

\section{Componentes del color}

La luminosidad de los pétalos disminuyó durante la vida poscosecha (Figura 1 B). La luminosidad fue afectada significativamente por la temperatura de almacenamiento ( $p \leq 0.05$; Tabla 1), así, las inflorescencias cambiaron de valores iniciales de $L^{*}$ entre 37.2 y 39.9 hasta 29.9 y 33.2 después de 10 días (Figura $1 \mathrm{~B}$ ), lo que indica que hubo una tendencia hacia el negro, atribuible a un oscurecimiento en los pétalos al senecer las flores.

La cromaticidad disminuyó significativamente en las inflorescencias $(p \leq 0.05)$, de valores iniciales de $C^{*}$ entre $37.7 \mathrm{y}$ 41.6 hasta 26.1 y 33.8 al final del experimento (Figura $1 \mathrm{C}$ ). Las flores almacenadas a $25^{\circ} \mathrm{C}$ fueron más opacas a partir del cuarto día de evaluación y esta tendencia se mantuvo hasta el final del experimento (Figura $1 \mathrm{C}$ ).

Por otra parte, el color de las inflorescencias fue afectado por la interacción IC $\times \mathrm{T}$ (Tabla 1). El color inicial de las inflorescencias de 'Magic Blue' fue cercano al morado ( $\mathrm{h}=$ entre 296.5 y 297.4), las flores mantenidas a $15^{\circ} \mathrm{C}$ mostraron poco cambio durante el estudio ( $h=$ entre 296.9 y 297 ), no así las inflorescencias que se almacenaron a $25^{\circ} \mathrm{C}$, en las cuales se observó una tendencia hacia el color azul ( $h=$ entre 294 y 295.8) (Tabla 1; Figura 1 D). Lo anterior indica que la temperatura aceleró el proceso de senescencia de la flor, lo cual se caracteriza por una oxidación de las antocianinas presentes en los pétalos (Oren-Shamir et al., 1999). En general los componentes del color se mantuvieron en mejor condicion cuando las flores se almacenaron a $15^{\circ} \mathrm{C}$. 


\section{Number of open flowers}

The number of open flowers was affected by the storage $\mathrm{HI}$ and $\mathrm{T}$, with no detection of the interaction between these two factors (Table 1). The inflorescences harvested with three open flowers and stored at $25{ }^{\circ} \mathrm{C}$ reached an average of 5.1 open flowers at the end of the experiment; in contrast, when stored at 15 ${ }^{\circ} \mathrm{C}$, they only reached 4.7 flowers in average (Figure $1 \mathrm{~F})$. When harvested with two open flowers and stored at $25^{\circ} \mathrm{C}$, the average number of open flowers in the inflorescences was 3.6, meanthile those stored at $15^{\circ} \mathrm{C}$ only opened an average of three flowers (Figure $1 \mathrm{~F})$. When harvested with one open flower and stored at $25^{\circ} \mathrm{C}$, the average of open flowers was three, while only two flowers opened when they were stored at 15 ${ }^{\circ} \mathrm{C}$ (Figure 1F). The latter indicates that independently from the harvest index (one, two or three open flowers), the number of flowers that open is not higher than two. Cut flowers are generally harvested in several development stages (Joyce and Faragher, 2012); in lisianthus, it is mentioned that one or more flowers are enough for commercialization (Dole and Wilkins, 2005).

\section{Appearance}

The variable of appearance was significantly affected by the storage temperature (Table 1 ). The appearance in lisianthus 'Magic Blue' stored at $15^{\circ} \mathrm{C}$ was between good and excellent after 7 days, while in the inflorescences kept at $25^{\circ} \mathrm{C}$, the appearance was regular and good at 7 days and regular at 10 days (Figure $1 \mathrm{~F}$ ). The storage at $15^{\circ} \mathrm{C}$ increased the shelf life in 3 days, compared to flowers stored at $25^{\circ} \mathrm{C}$ (Figure 1 F). Harbaugh et al., (2000) evaluated the varieties of lisianthus, indicating shelf life between 6 and 21 days. This report is one of the first works were the shelf life postharvest in varieties of lisianthus developed in warm weather conditions in Mexico is informed.

\section{Water consumption}

Water consumption was affected by the interaction of the storage $\mathrm{HI}$ and $\mathrm{T}$ (Table 1). Hence, water consumption was higher when the inflorescences were harvested with three open flowers and kept at $15{ }^{\circ} \mathrm{C}$ (Figure 1G). Van Doorn (2012) indicates that these can be due to a higher transpiration of the leaves, since in most of the species the stomas of the petals are not functional. Liao et al., (2001) indicate that higher water consumption of the flowers of lisianthus induces to a higher turgency of the petals. Results reflect that stored

\section{Número de flores abiertas}

El número de flores abiertas fue afectado por el IC y por la T de almacenamiento, sin detectarse interacción entre estos dos factores (Tabla 1). Las inflorescencias cosechadas con tres flores abiertas y almacenadas a $25^{\circ} \mathrm{C}$ alcanzaron en promedio 5.1 flores abiertas al final del experimento, en tanto que cuando se almacenaron a $15^{\circ} \mathrm{C}$ solo alcanzaron 4.7 flores en promedio (Figura $1 \mathrm{~F}$ ). Cuando se cosecharon con dos flores abiertas y se almacenaron a $25^{\circ} \mathrm{C}$ el número promedio de flores abiertas en las inflorescencias fue de 3.6, en tanto que las almacenadas a $15^{\circ} \mathrm{C}$ sólo abrieron en promedio tres flores (Figura $1 \mathrm{~F}$ ). Cuando se cosecharon con una flor abierta y se almacenaron a $25^{\circ} \mathrm{C}$ el número promedio de flores abiertas fue de tres, mientras que solo dos flores abrieron cuando se almacenaron a $15^{\circ} \mathrm{C}$ (Figura $1 \mathrm{~F}$ ). Lo anterior indica que independientemente del índice de cosecha (uno, dos o tres flores abiertas) el número de flores que abren no es mayor a dos. Las flores de corte generalmente son cosechadas en varias etapas de desarrollo (Joyce y Faragher, 2012); en lisianthus se menciona que con una o más flores es suficiente para su comercialización (Dole y Wilkins, 2005).

\section{Apariencia}

La variable apariencia fue afectada significativamente por la temperatura de almacenamiento (Cuadro 1). La apariencia en lisianthus 'Blue Magic' almacenadas a $15^{\circ} \mathrm{C}$ fue entre buena y excelente después de siete días, en tanto que en las inflorescencias mantenidas a $25^{\circ} \mathrm{C}$ la apariencia fue entre regular y buena a los siete días y regular a los 10 días (Figura $1 \mathrm{~F}$ ). El almacenamiento a $15^{\circ} \mathrm{C}$ incrementó la vida útil en tres días comparadas con las flores almacenadas a 25 ${ }^{\circ} \mathrm{C}$ (Figura $1 \mathrm{~F}$ ). Harbaugh et al., (2000) evaluaron variedades de lisianthus indicando una vida útil entre seis y 21 días. El presente reporte es de los primeros trabajos donde se informa sobre la vida útil en poscosecha de variedades de lisianthus desarrolladas en condiciones de clima cálido en México.

\section{Consumo de agua}

El consumo de agua fue afectado por la interacción del IC y la T de almacenamiento (Tabla 1). Así, el consumo de agua fue mayor cuando las inflorescencias se cosecharon con tres flores abiertas y se mantuvieron a $15^{\circ} \mathrm{C}$ (Figura $1 \mathrm{G}$ ). Van Doorn (2012) indica que esto se puede deber a una mayor transpiración de las hojas, debido a que en la mayoría de las especies los estomas de los pétalos no son funcionales. Liao et al., (2001) indican que el mayor consumo de agua en las flores de lisianthus induce a una mayor turgencia de los pétalos.Los resultados reflejan que las inflorescencias almacenadas 
inflorescences at $15{ }^{\circ} \mathrm{C}$ and with three inflorescences conserve turgency for longer time (Figure 1F). Inflorescences kept at $25{ }^{\circ} \mathrm{C}$ showed lower water consumption, probably because at higher temperature the velocity of bacteria development is also higher, which causes the occlusion of the vascular bundles (Cruz-Crespo et al., 2006).

\section{Conclusions}

Storage at $15^{\circ} \mathrm{C}$ kept better appearance and color components $L^{*}$ and $C^{*}$ of lisianthus 'Magic Blue', and when harvested with three open flowers and stored at $15{ }^{\circ} \mathrm{C}$, relative fresh weight and water consumption was higher. In the before mentioned conditions, shelf life of lisianthus is $13 \mathrm{~d}$. The number of open flowers after the harvest is two.

\section{Ackonwledgements}

The first author thanks CONACyT for granting post-grade scholarship. In addition, the support of the Academic Technician Alyn Mariana Palacios Sosa in the evaluation of this experiment is acknowledged by the authors. a $15^{\circ} \mathrm{C}$ y con tres inflorescencias conservaron su turgencia por más tiempo (Figura 1 F). Las inflorescencias mantenidas a $25^{\circ} \mathrm{C}$ mostraron un menor consumo de agua, probablemente debido a que a mayor temperatura la velocidad de desarrollo de bacterias también es mayor lo que ocasiona la oclusión de los haces vasculares (Cruz-Crespo et al., 2006).

\section{Conclusiones}

El almacenamiento a $15{ }^{\circ} \mathrm{C}$ mantuvo mejor apariencia y los componentes del color $L^{*}$ y $C^{*}$ de lisianthus 'Magic Blue', y cuando se cosecharon con tres flores abiertas y se almacenaron a $15^{\circ} \mathrm{C}$, el peso fresco relativo y el consumo de agua fue mayor. En las condiciones antes mencionadas la vida útil del lisianthus es de $13 \mathrm{~d}$. El número de flores abiertas después de la cosecha es de dos.

\section{Agradecimientos}

El primer autor agradece al CONACyT por otorgar beca para estudios de posgrado. Así mismo se agradece el apoyo de la Técnico Académico Alyn Mariana Palacios Sosa por su apoyo en la evaluación del presente experimento.

\section{References}

Ahmad, I., Dole, J., Amjad, A. and Ahmad, S. 2012. Dry storage effects on postharvest performance of selected cut flowers. HorTechnology 22(4): 463-469. http://horttech.ashspublications.org/content/22/4/463.full

Chamani, E., Arshad, M. and Pourbeyrami, Y. 2009. Response of various cut lisisanthus cultivars to silver thiosulfate treatment. Journal of Food, Agriculture and Enviroment 7(2): 746-748. https://www.researchgate.net/publication/255604968 Response of various cut lisianthus cultivars to silver thiosulfate treatment

Castillo, M.L.E. 2011. Introducción al SAS® para windows. Universidad Autónoma Chapingo. 3era. Edición. Chapingo, Estado de México, México. 295 pp. http://parasitologia.chapingo.mx/produccion/libros/1-introduccin-al-sas-parawindows-3ra-edicin

Cevallos J.C. and Reid, M.S. 2001. Effect of dry and wet storage at different temperatures on the base life of cut flowers. HorTechnology 11 (2): 199-202. http://horttech.ashspublications.org/content/11/2/199.full.pdf+html

Cho, M.S., Celikel, F.G., and Dodge, L., M.S. 2001 Sucrose enhances the postharvest quality of cut flowers of Eustoma grandiflorum (Raf.) Shinn. Acta Horticulturae 543: 305-315. http://www.ishs.org/ishs-article/543 37

Cruz-Crespo, E., Arévalo-Galarza, L., Cano-Medrano, R. and Gaytán-Acuña E.A. 2006. Soluciones pulso en la calidad poscosecha de lisianthus (Eustoma grandiflorum Raf. Shinn) cv. 'Echo Blue'. Agricultura Técnica en México 32(2): 191-200. http://www.redalyc.org/articulo.oa?id=60832207

De la Riva F., Mazuela, P.C. Álvaro, J.E. and Urrestarazu, M. 2009. Treatment with peracetic acid extends the base life of lisianthus (Eustoma grandiflorum) flowers. HortScience 44(2): 418-420. http://hortsci.ashspublications.org/ content/44/2/418.full

Dole, J.M. and Wilkins, H.F. 2005. Floriculture. Principles and Species. Pearson Prentice Hall. 1021 pp. 
Finger, L.F., Silva, T.P. Araujo, F.F., Barbosa, J.G. 2015. Postharvest Quality of Ornamental Plants. pp: 81-108. En: Postharvest Ripening Physiology of Crops. Pareek, S. (Ed.). CRC Press-Taylor \& Francis. https://www.crcpress.com/ Postharvest-Ripening-Physiology-of-Crops/Pareek/p/book/9781498703802

Harbaugh, K.B., Bell, M.L. and Liang, R. 2000. Evaluation of forty-seven cultivars of lisianthus as cut flower. HorTechnology 10(4): 812-815. http://horttech.ashspublications.org/content/10/4/812.abstract

Hassanpour, M. and Karimi, M. 2010. Efficiency of bencyladenine reduced ethylene production -and extended base life of cut Eustoma flowers. Plant Omics Journal 3: 199-203. http://www.pomics.com/hassanpour 362010199 203.pdf

Huxley, A.M., Griffiths, M. and Levy, M. 1992 Eustoma. pp: 271. En: The New Royal Horticultural Society Dictionary of Gardening. V. 2. Stockton Press. New York. http://trove. nla.gov.au/work/6052770?q\&versionld=42648724

Islam, N., Patil, G.G. and Gislrod, H.R. 2003. Effects of pre and postharvest conditions on vase life of Eustoma grandiflorum (Raf.) Shinn. European Journal of Horticultural Science 68(6):272-278. https://www.jstor.org/stable/24126148

Joyce, D. and Faragher, J. 2012. Cut Flowers. pp: 414-438. En: Rees, D., G. Farrel, J. Orchard. Crop Postharvest: Science and Technology. Blackwell Publishing.

Kazemi, M., Aran, M. and Zamani, S. 2011. Extending the vase life of lisianthus (Eustoma grandiflorum cv. Blue) with different preservatives. American Journal of Plant Physiology 6(3): 167-175. DOI: 10.3923/ajpp.2011.167.175 http://docsdrive.com/pdfs/academicjournals/ajpp/2011/167-175.pdf

Liao, L-J., Lin, Y.-H. Huang, K.-L., and Chen, W.-S. 2001. Vase life of Eustoma grandiflorum as affected by aluminium sulfate. Bot. Bull. Acad. Sin. 42: 35-38. https://ejournal.sinica.edu.tw/bbas/content/2001/1/bot421-05.htm/

Namesny, A. 2005. De lisianthus a capsicum mejora genética en ornamentales. Horticultura 47:34-37.http://www.horticom. com/pd/imagenes/59/038/59038.html\#2

Negueruela, I. A. 2012. Is the color measured in food the color that we see? In: Color Food Technological and Psychophysical Aspects. Cavanino J L, Buera P de M (eds.) CRC Press Taylos \& Francis. Boca Raton, Florida, USA. pp:81-91.

Nell, T. A., and Reid, M. 2002. Poscosecha de las flores y plantas. Ediciones Horticiencia. Bogotá, Colombia. 216 p.

Pérez-Arias, G.A., Alia-Tejacal, I., Valdez-Aguilar, L.A. Colinas-León, M.T., López-Martínez, V. and Sainz-Aispuro, M. de J. 2014. La refrigeración en húmedo y seco afecta la vida poscosecha de flores de corte de Li- sianthus (Eustoma grandiflorum) 'ABC Blue Rim'. Revista Mexicana de Ciencias Agrícolas 5(7): 1247- 1260. http://www.scielo.org.mx/pdf/remexca/v5n7/v5n7a9.pdf

Oren-Shamir, M., Shaked-Sachray, L., Nissim-Levi, A. and Ecker, R. 1999. Anthocyanin pigmentation of lisianthus flower petals. Plant Science 140(1): 81-86 DOI: https://doi.org/10.1016/S0168-9452(98)00198-8. http://www.sciencedirect.com/science/article/pii/S0168945298001988

Reid, M. and Jiang, C.Z. 2012. Postharvest Biology and Technology of Cut Flowers and Potted Plants. Horticultural Reviews 40: 1-53. http://ucanr.edu/datastorefiles/234-2469.pdf

USDA National Agricultural Statics Service. 2012. Floriculture Crops 2011 Summary. 58 p. http://usda.mannlib.cornell.edu/ usda/nass/FlorCrop//2010s/2012/FlorCrop-05-31-2012.pdf

Van-Doorn, G. 2012. Water relations of cut flowers: An Update. Horticultural Reviews 40: 55-106. DOI: $10.1002 /$ 9781118351871.ch2 http://onlinelibrary. wiley.com/doi/10.1002/9781118351871.ch2/summary

Cite this paper/Como citar este artículo: Pérez-Arias, G.A., Alia-Tejacal, I., Valdez-Aguilar, L.A., Colinas-León, M.T., Sainz-Aispuro, M. (2017). Harvest Index And Refrigeration In Lisianthus (Eustoma grandiflorum (Raf.) Shin.) 'Magic Blue'. Revista Bio Ciencias 4(5), 10 pages, Article ID: 04.05.06. http://dx.doi.org/10.15741/ revbio.04.05.06 